\title{
A performatização da poética da desumanização: errância do sujeito e da escrita literária
}

\author{
Elisabete Alfeld*
}

\begin{abstract}
Resumo
Em A desumanização (MÃE, 2014), Halla, narradora e personagem, transitando pela natureza fabulosa dos fiordes, conta a sua história enredando rastros de lembranças e de memórias lendárias com o que resta para viver. Nesse contar, a escrita literária revela "uma linguagem duplicada, já que, ao mesmo tempo que conta uma história, que conta alguma coisa, deverá, a cada instante, mostrar e tornar visível o que a literatura é, o que a linguagem da literatura é" (FOUCAULT, 2016, p. 90). O objetivo que norteia este estudo pretende abordar, na escritura do romance, os aspectos performáticos da escrita literária que, a partir da poética da desumanização, configura a errância do sujeito que transita entre a vida e a morte e a errância da escrita que transita entre a prosa e a poesia; entre a ficção e o ensaio poético.
\end{abstract}

Palavras-chave: A desumanização. Performatização de errâncias. Escrita literária.

\section{The performatization of the poetics of dehumanization: Wandering of the subject and literary writing}

\begin{abstract}
In Dehumanization (MÃE, 2014), Halla, narrator and character, transiting the fabulous nature of the fjords, tells his story entangled traces of memories and legendary memories with what remains to live. In this account, literary writing reveals "a duplicate language, since, at the same time that it tells a story, which tells something, it must at every moment show and make visible what literature is, what the language of literature is "(FOUCAULT, 2016, p.90). The objective that guides this study that intends to approach in the writing of the novel the performatic aspects of the literary writing that, from the poetics of the dehumanization, configures the wanderings of the subject that transits between life and death and the wandering of writing that transits between prose and poetry; between fiction and poetic essay.
\end{abstract}

Keywords: A desumanização. Performatization of errors. Literary writing.

Recebido: 30/01/2019

Aceito: 24/04/2019

\footnotetext{
* Pontifícia Universidade Católica de São Paulo (PUC - SP). Doutora em Comunicação e Semiótica pelo Programa de Estudos Pós-Graduados em Comunicação e Semiótica. Professora do Departamento de Arte da Faculdade de Filosofia, Comunicação, Letras e Artes (PUC SP).
} 


\section{Apresentação da poética da desumanização}

[...] a literatura contemporânea tem de ser mais do que literatura: uma experiência vital, um instrumento de descoberta, um meio para o homem de se por à prova, de se tentar, e nessa tentativa buscar ultrapassar os seus limites. BLANCHOT, 2011b, p. 222).

A citação destaca um dos traços construtivos do romance contemporâneo: a literatura como experiência e instrumento de descoberta. Esta perspectiva direcionada para questões relativas às formas de narrar e à construção do sujeito situa a literatura em um campo experimental: espaço aberto à criação que possibilita novas formas de dizer para escrever/experienciar a linguagem e com isso construir novas subjetividades alicerçadas em uma escrita performática. A performance é definida como uma modalidade cênica - atuantes e espectadores num determinado espaço e tempo - que pressupõe a obra em processo (work in process), caracterizando-se como uma arte de fronteira, quer entre "as artes plásticas e as artes cênicas", quer "tocando nos tênues limites que separaram vida e arte" (COHEN, 2002, p. 30; 38). Performance é uma linguagem de experimentação e "uma arte de intervenção, modificadora, que visa causar uma transformação no espectador." (COHEN, 2002, p. 46). A enumeração de tais traços é suficiente para diferenciar os formatos performance e romance e, também, para aproximá-los no que concerne à experimentação de linguagem, modos de contar, a relação com o espectador/leitor e ser uma arte de fronteira. Caracterizar a escrita do romance como uma escrita performática é considerar que a escritura do romance incorpora o significado estendido da performance criando/sugerindo na interface entre o linguístico e o cênico o caráter performático da escrita literária.

Essas considerações desmistificam a função representativa da literatura, aspecto esse já apontado por Blanchot (2011b) ao dizer que a literatura não representa, ela apresenta e, para isso, a escrita literária afasta-se do mimetismo e coloca em cena o caráter performático da linguagem para dar conta de dizer o que se instala, por exemplo, no limite entre vida e morte; no limite entre prosa e poesia. Em A desumanização (MÃE, 2014), Halla, narradora e personagem, começa a sua história com o advento da morte: "Foram dizer-me que a plantavam. Havia de nascer outra vez, igual a uma semente atirada àquele bocado muito guardado de terra [...]. Éramos gémeas. Crianças espelho.” (MÃE, 2014, p. 9). A morte leva à cisão ${ }^{1}$ que define o plot desencadeador do enredo: contar, ao mesmo tempo, sobre o depois e o antes da morte e, principalmente, contar sobre a cisão do sujeito - "Tudo em meu redor se dividiu por metade com a morte" (MÃE, 2014, p. 9) -: "Começaram a dizer as irmãs mortas. A mais morta e a menos morta. Obrigada a andar cheia de almas, eu era um fantasma." (MÃE, 2014, p. 13). Halla, para entender a perda, vai subverter a morte sob o olhar do onírico:

Nos meus sonhos imaginava jardins de crianças. As árvores baixas dos corpos, falando, brincando com os pássaros pousando entre as folhas. Os braços deitavam folhas e seguravam ninhos nas mãos e as crianças eram sempre pequenas, animadas de ingenuidade, gratas pela vida sem saberem outra coisa que não a vida. E sonhava que as pessoas japonesas vinham ao jardim contemplar, e deitavam água de regadores coloridos que lavavam os pésraízes das crianças bonsai. E só de noite, quando bem escuro, alguém vinha com as facas para laminar as partes dos corpos que se alongavam. Laminavam cuidadosamente, todas as noites, para que não deformassem as crianças, para que avelhassem sem se notar. Incapazes de mostrar a idade. Apenas livres para usarem a idade na manutenção eufórica da infância. Sofreriam os cortes caladas. Conscientes da maravilha que aquela dor lhes trazia. (MÃE, 2014, p. 12).

1 Cisão que também está presente no projeto gráfico do livro: páginas, em negro, espelhadas para apresentar o romance (a editora, o título, a dedicatória, a epígrafe e anunciar a primeira parte do romance); página em negro para fazer a passagem da primeira para a segunda parte do romance; páginas em negro intercaladas com as páginas finais para separar a nota do autor e sobre o autor. 
Halla, frente à impossibilidade da 'manutenção eufórica da infância' com o rompimento do fio da vida, deseja ser uma criança bonsai para eternizar as identidades espelhadas: "O único modo de continuarmos gémeas. Sabes, pai [...] Faz de mim um bonsai. Peço-te. Corta o meu corpo, impede-o de mudar." (MÃE, 2014, p. 11-12). Rompido o elo entre as gêmeas, sobra apenas o fio que é atado textualmente e, para isso, a solução simbólica é projetar-se na existência poeticamente inventada, situada nas ambivalências 'do tudo ou do nada', na metaforização, nas alegorias e nos demais procedimentos estéticos presentes na escrita do romance. À personagem-narradora compete atravessar as passagens labirínticas, tramadas por diferentes forças motivadas ora pela natureza, ora pela morte que subjuga a vida. Halla encontra-se, portanto, em uma situação paradoxal e liminar: busca a morte e lamenta a vida, como criança-espelho, falta-lhe a outra metade; transita entre a realidade e o imaginário na existência poeticamente inventada. 'Estar entre' é índice de um sujeito errante que "vagueia de um lugar a outro, sem poder e sem destino" (BLANCHOT, 2005, p. 323). Na escritura do romance, a 'errância' é recurso estético presente na escrita que transita entre a prosa e a poesia:

O pequeno tanque branco, pensei, podia ser uma página. Os peixes debatendo-se podiam ser um poema. Chamei o meu pai. Disse-lhe que os poemas deviam ser assim, como caixas onde estivesse tudo contido e onde, por definição, pudéssemos entrar também. Caixas gigantes, se fosse necessário. Adequadas ao tamanho do que se quisesse dizer. Do que se quisesse guardar. E os peixes como versos que podemos tocar. Pai. Que podemos tocar. Esses versos convencem-me, os outros, não. (MÃE, 2014, p. 32).

Na fala poética, afirma Blanchot (2011a, p. 35), a linguagem assume toda a sua importância, torna-se o essencial, e as palavras não devem servir para designar alguma coisa nem para dar voz a ninguém, mas têm em si mesmas seus fins; a escrita literária caracteriza-se por ser "uma linguagem duplicada, já que, ao mesmo tempo que conta uma história, que conta alguma coisa, deverá, a cada instante, mostrar e tornar visível o que a literatura é, o que a linguagem da literatura é" (FOUCAULT, 2016, p. 90). O objetivo que norteia este estudo pretende abordar na escritura do romance os aspectos performáticos da escrita literária que, a partir da poética da desumanização, configura a errância do sujeito que transita entre a vida e a morte e a errância da escrita que transita entre a prosa e a poesia; entre a ficção e o ensaio poético.

\section{O sujeito errante: subjetividades em espelhamento}

Quando nos virmos ao espelho e só ali estiver a alma vamos pasmar de maravilha. Maravilhadas com o que somos ou sabemos ser. Viveremos apenas nas costas dos olhos. Entendes. Seremos apenas as costas dos olhos. O lado de dentro. (MÃE, 2014, p. 25).

"Quando nos virmos" 'eus' imaginados e projetados - a imagem de Halla a partir do outro e para o outro, a irmã morta - êxtase futuro trapaceando com o presente - "sem a Sigridur tudo perdera o conteúdo. Estava oco. Como se ela fosse o dentro de tudo" (MÃE, 2014, p. 36). Tradução do interno no externo performatizado no espelhamento da linguagem - maravilha/maravilhadas. Duplicidades enganadoras pois que o 'encontro' se situa em um lugar sem lugar, um espaço irreal (o espelho); num tempo sem tempo, que está por vir (quando) e em corpos sem corpos - quando só ali estiver a alma. A palavra espelho é metaforizada nos duplos: morte/vida; duas almas; Halla/Sigridur; Halla/Einar; Einar/Einar. "Um espelho [...]. Era a mais profunda ilusão. O meu corpo todo ali replicado, como se outra vez fôssemos duas." (MÃE, 2014, p. 115). Para construir a escrita desse contar pautado pela falta, Halla vai se espelhar no discurso do pai que colocava "versos no lugar de cada coisa". Quem 
sonda o verso, diz Blanchot (2011b, p. 31), escapa ao ser como certeza, rompe com tudo, não tem a verdade por horizonte nem o futuro por morada. Halla quer chamar a vida de poema para escapar do presente sofrido e refugiar-se nas recordações, o que permite transitar entre a realidade e a fantasia. Estar entre a fantasia e a realidade define a ambivalência da personagem-narradora a morta/viva que no presente recupera o passado. Na escrita literária, a ambivalência é construída pela linguagem poética, isto porque "a poesia não responde ao apelo das coisas. Ela não está destinada a preserválas, nomeando-as. Pelo contrário, a linguagem poética é a maravilha de transpor um fato natural para seu quase desaparecimento vibratório." (BLANCHOT, 2005, p. 330, grifos do autor). Halla narrativiza poeticamente os fatos da vida e da morte na linguagem que está em íntima relação com a natureza fabulosa da Islândia:

A ver a imensidão dos fiordes, as montanhas de pedra cortadas por rigor, o movimento nenhum, achei que o mundo mostrava a beleza mas só sabia produzir o horror. [...] Era tudo velho. A gente, os sonhos, os medos e as montanhas. [...] Contava-se que deus se sentara pelos fiordes e, de rabo tão pesado, a rocha cedera como se fosse um monte de areia. Outras pessoas achavam que aquilo era do diabo, descansando de andar a acender caldeiras, regurgitando as almas dos infelizes para dentro das crateras fundas dos vulcões, enchendo os vulcões do estranho ódio que o fogo continha. Jurava o meu pai: é um estranho ódio que o fogo contém. Deve vir dos mal mortos. Os zangados. [...] Eu achava que a marca grande na montanha era do rabo de deus. Porque o mar continuava fresco e sem receios. Muito fundo. O mar era um diamante líquido. Eu respondia: o mar também pensa. $\mathrm{O}$ meu pai sorria. Os peixes nadavam dentro de um diamante. No sangue de cristal. (MÃE, 2014, p. 12,31).

A natureza metaforizada é passagem para o imaginário - "Achei que a minha irmã podia brotar numa árvore de músculos, com ramos de ossos a deitar flores de unhas" (MÃE, 2014, p. 9) - mas um imaginário inscrito na poética da desumanização: "Achei que a morte seria igual à imaginação, entre o encantado e o terrível, cheia de brilhos e susto, feita de ser ao acaso. [...]. Imaginar era como morrer." (MÃE, 2014, p. 9-10). O que Halla conta compreende o que se passou dos onze aos treze anos; no entanto a temporalidade narrativa não é definida por essa cronologia, o que vai definir o tempo é o sentimento de tristeza; o tempo "se conta pelos desgostos" - "A tristeza colocara os meus pais e as coisas todas a envelhecer.” (MÃE, 2014, p. 39). O sentimento de profunda tristeza envolve o que sobrou depois da morte de Sigridur: uma mãe que "despedaçava os animais para a expiação louca da dor" (MÃE, 2014, p. 14), uma mãe que "perdera o modo de se apaziguar [...] não desculpava ninguém e não se desculpava [...]. Como se estivesse viva num mundo morto" (MÃE, 2014, p. 27): "Por vezes, a minha mãe sangrava nos pratos. Enquanto os lavava, os cortes dos braços abriam a sujar a água. Vingava-se de si mesma por não ter sabido salvar uma filha.” (MÃE, 2014, p. 33); automutilação e mutilação de Halla: "Quando acordei, a minha mãe desfizera-me um mamilo. A pele falhava. O sangue já seco não escondia os cortes. As dores eram profundas.” (MÃE, 2014, p. 33).

Enquanto a mãe a odeia, culpa-a e a mutila, o pai é o contraponto: "pensador", "fantasioso", um nervoso sonhador", é cúmplice no sofrimento silencioso. Com ele Halla aprendeu que o inferno não são os outros, eles "são o paraíso, porque um homem sozinho é apenas um animal" (MÃE, 2014, p. 15). A vida arrebatada pela morte deixa o vazio - "Andava por ali a ver no vazio coisas de mentira. Andava a ver o vazio das coisas." (MÃE, 2014, p. 36) - da mesma forma que a palavra que não comunica deixa um vazio - "As palavras são objetos magros incapazes de conter o mundo" (MÃE, 2014, p. 27); a palavra, uma vez incompleta, não realiza a potência comunicativa da linguagem. Isto porque a especificidade da linguagem humana consiste "no fato de que, único entre os seres vivos, o homem não se limitou a adquirir a linguagem como uma capacidade entre outras de que é dotado, mas fez dela a sua potência específica, ou seja, na linguagem ele pôs em jogo a sua própria natureza." (AGAMBEN, 2011, p. 79, grifos do autor), o que significa vincular "em um nexo ético 
e político, as palavras, as coisas e as ações" para com isso "ser produzido algo como uma história, distinta da natureza e, no entanto, inseparavelmente entrelaçada com ela." (AGAMBEN, 2011, p. 80). Segundo Agamben, o elemento decisivo que confere à linguagem humana as suas virtudes peculiares não reside no instrumento em si mesmo, mas sim no lugar que ele confere ao ser que fala, enquanto disponibiliza dentro de si uma forma de vazio que o locutor toda vez deve assumir para falar. Para o autor, "O homem é o ser vivo que, para falar, deve dizer "eu”, ou seja, deve "tomar a palavra", assumi-la e torná-la própria." (AGAMBEN, 2011, p. 82, grifos do autor). Para Halla, tomar a palavra para si, ainda era um desejo:

Queria uma palavra alarve, muito gorda, uma que usasse todo o alfabeto e muitas vezes, até não se bastar com letras e sons e exigisse pedras e pedaços de vento, as crinas dos cavalos e a fundura da água, o tamanho da boca de deus, o medo todo e a esperança. Uma palavra alarve que fosse tão feita de tudo que, quando dita, pousasse no chão definitivamente, sem se ir embora para que a pudéssemos abraçar. Beijar. (MÃE, 2014, p. 30).

Essa palavra desejada só será alcançada quando for desfeito o elo entre as gêmeas, quando Halla compreender "que a Sigridur era o passado. Estava posta no passado" (MÃE, 2014, p. 89). Mas, até chegar a esse momento, Halla precisa preencher o vazio deixado pela Sigridur, precisa "inventar que vivia no passado" (MÃE, 2014, p. 53) e, para isso, potencializa pela palavra a presença 'viva' da irmã. Palavra, também, proferida para enganar a solidão, palavra anunciadora da vontade de fugir; porque fugir era uma maneira de sentir-se longe e querer ser longe era o desejo da Sigridur: "Quando for grande, quero ser de outra maneira. Quero ser longe.” (MÃE, 2014, p. 22). Para Halla, a maior distância era a morte pois com a morte voltariam a ser gêmeas mais tarde quando ela se "demitisse do poema" (MÃE, 2014, p. 55).

O contar de Halla está contaminado pelo maravilhoso, ainda que esse contar esteja alicerçado sob o desencanto. Tal estado motiva a expressividade da linguagem, por sua vez, alicerçada sob as normas da poética: metaforizar para sugerir a densidade dramática das imagens e concentrar na reiteração de palavras, de expressões ou mesmo de fragmentos de orações, a intensidade do narrado e suas ambivalências de modo a construir frases e orações em quase-versos; é a prosa que quer ser poesia: “O pior amor é este, o que já é feito de ódio também. O pior amor é este, o que já é feito de ódio também. O pior amor é este, o que já é feito de ódio também.” (MÃE, 2014, p. 89). Para a construção do efeito poético convergem: a reiteração de palavras que, linguisticamente, cria, no desenvolvimento da narrativa, as ambivalências amor-e-ódio, morte-e-vida, realidade-e-sonho, apoiadas na construção sintática das orações; a pontuação que obriga as paradas da leitura e o ritmo. $\mathrm{Na}$ escrita, essa sintaxe sugere quase-versos uma vez que autoriza a palavra a ausentar-se de seu uso utilitário nas vezes em que a palavra "ficava apenas para ser dita sem a capacidade alguma de chegar ao destino.” (MÃE, 2014, p. 83). A literatura tem esse poder de arrancar a palavra do uso utilitário da língua para ler-ouvir poeticamente as palavras de modo a metamorfosear o prosaico em poético. Para tanto, a literatura intervém para anunciar, na história de Halla, que as palavras que não são nada não devem ser enunciadas:

Com trinta e duas letras num alfabeto não criamos mais do que objetos equivalentes entre si, todos irmanados na sua ilusão. As letras da palavra cavalo não galopam, nem as do fogo bruxuleiam. E que importa como se diz cavalo ou fogo se não se autonomizam do abecedário. (MÃE, 2014, p.29).

Importa, portanto, para a criação literária, a palavra poética, porque os poemas são “ instintivos como um candeeiro dentro da cabeça" (MÃE, 2014, p. 104); porque os poemas "podem ser completos como muito do tempo e do espaço. Podem ser verdadeiramente lugares dentro dos quais passamos a viver.” (MÃE, 2014, p. 138). É por meio do poético que entramos na história de Halla; é, também, por 
meio do poético que desembaraçamos o fio narrativo do romance: "Ela estendida como um verso." (MÃE, 2014, p. 32). A comparação serve para contar sobre a irmã morta; serve mais ainda para mostrar qual é a linguagem que conta sobre a morte: é a linguagem que conta sobre o vazio e o oco das palavras. É, também, por meio do poético que a natureza se revela: "No lugar da Islândia colocar um poema." (MÃE, 2014, p. 123), porque na Islândia, "era preciso estar preparado para a substituição poética das coisas." (MÃE, 2014, p. 43), uma vez que o que está sendo contado sobre (e com) a Islândia está impregnado de referenciais míticos e lendários:

Contava-se que, num tempo inicial, voavam dragões famintos que devoravam tudo quanto lhes adoçasse as entranhas zangadas. Contava-se que, devastadas as coisas todas, os dragões haviam perdido a capacidade de voar e haviam parado exaustos um pouco por toda a parte. Arfavam e empederniram. Dizia-se que, de tão grandes e espessas peles, haviam radicado como montanhas de boca aberta. Passados infinitos séculos, alguns fumegavam ainda. Algumas bocas, no resto da raiva que continham, cuspiam fogo, já como dragões de pedra. Bichos gordos absolutamente feitos de pedras. Era engraçado olhar para as montanhas da Islândia e imaginar dragões acotovelados. Gigantes e cansados, mas talvez ainda ferroando-se e chamuscando-se uns aos outros por dentro. Culpados e culpando-se de terem tido tanta gula e tanta incúria. (MÃE, 2014, p. 42).

Contava-se, dizia-se - rememorar essas histórias primordiais trazendo para a sua história essa segunda realidade simbólica e lendária fundada na oralidade e em uma memória que resgata os princípios primordiais vinculadores do homem ao cosmos. Diz Eliade (1991, p. 25), que toda "história mítica que relata a origem de alguma coisa pressupõe e prolonga a cosmogonia." Recitar a origem equivale a interpretar uma mensagem divina e a restaurar o processo da criação; significa, também, a decodificação desse universo simbólico como matéria do ficcional. Por isso, a representação lendária e mítica é carregada de espiritualidade - "Onde há a palavra, há deus. Onde nasce a palavra, nasce deus." (MÃE, 2014, p. 45) - e qualifica o espaço da ação narrativa - "Os homens sós percebem que há alguém na água, na pedra, no vento, no fogo. Há alguém na terra.” (MÃE, 2014, p. 15). Halla, quando reatualiza os vínculos simbólicos com a natureza da Islândia, atribui-lhes uma função encantatória e recordar essa memória do começo pode ser lida como uma estratégia de criação do mundo fictício pautado por esse imaginário contagiado pela cosmogonia. O imaginário é "o grande denominador fundamental onde se vêm encontrar todas as criações do pensamento humano." (DURAND, 2002, p. 18). Para Morin (1980, p. 74), o “imaginário é a prática espontânea do espírito que sonha” é, também, o "lugar-comum da imagem e da imaginação". Nas palavras do autor, entra-se no reino do imaginário no momento em que as aspirações, os desejos, e os seus negativos, os receios e os terrores, captam e modelam a imagem, com vistas a ordenarem, segundo a sua lógica, os sonhos, os mitos, as religiões, as crenças, as literaturas, ou seja, precisamente todas as ficções. Halla utiliza essas mediações simbólicas como campo de referência para desnudar a desumanização, pois revestindo-a da função encantatória desreferencializa o real e institui a realidade imaginada contaminada pela cosmogonia emblemática da paisagem: as águas quentes eram "esperadoras, cheias de segredos e inteligências antigas"; os vulcões em erupção "eram montanhas voadoras que alavam sobre as cabeças de toda a gente"; as "auroras cavalgavam. Subiam e desciam ondas"; "o fogo era a mão quente de deus. Estendida sobre nós por generosidade.” (MÃE, 2014). Os elementos da natureza, em movimento, são metaforizados em seres plenos de vida.

A natureza é, portanto, um espaço sacralizado, pois, como afirma Eliade (1995, p. 33), "o sagrado revela a realidade absoluta e, ao mesmo tempo, torna possível a orientação"; nas palavras do autor, funda o mundo, no sentido de que fixa os limites e, assim, estabelece a ordem cósmica. A experiência do sagrado é o que proporciona à Halla criar a sua realidade imaginária, ainda que sob a perspectiva da imagem opressora da morte, pois o mundo natural, contaminado pelo imaginário, revela-se, simbolicamente, caracterizado como uma entidade, ou melhor, como várias entidades: “A 
terra $^{2}$ estava infestada de seres matadores, invejosos, gulosos da felicidade dos outros. Comem-lhe a felicidade." (MÃE, 2014, p. 11); a boca de deus era "o poço infinito que nos servia de sentença para cada coisa. O que para ali atirássemos ficava tão só na imaginação" (MÃE, 2014, p. 17); as águas eram "sonambulas"; "As pedras conspiram. Magicam maneiras de viver." (MÃE, 2014, p. 44); o nevoeiro que chegava ao entardecer era como "um gato gigante aninhado sobre os fiordes." (MÃE, 2014, p. 52); a rocha extensa dos fiordes, cabeça adentrando o mar "para nos matar a todos." (MÃE, 2014, p. 67); "o inverno pensante, pormenorizadamente infligido aos fiordes, sem piedade e sem negociação. (MÃE, 2014, p. 106). Como entidade, o mundo natural revela-se como um "Cosmos vivente, articulado e significativo." (ELIADE, 1991, p. 125).

A natureza, por meio de seu próprio modo de ser, de suas estruturas e de seus ritmos, desvenda-se enquanto linguagem uma vez que a Islândia "era entidade, coisa de ver e pensar, dotada de memória e a planear quietamente o futuro.” (MÃE, 2014, p. 95). A Islândia deixa de ser paisagem, é uma personagem, e como personagem - "a Islândia pensa. A Islândia é temperamental, imatura como as crianças, [...]. Por viver a infância, decide com muito erro, agressiva e exuberantemente.” (MÃE, 2014, p. 30). E, por ser personagem, tem autoridade para intervir sobre a ventura da vida: "Até então, e avisada pelo meu pai, esperei sempre os meus predadores criados pela decisão da Islândia. Os temperamentos da Islândia. Fossem as águas ou os fogos, fossem os ventos ou a pedra que se abrisse sob meus pés.” (MÃE, 2014, p. 72). Como personagem, a Islândia trama as passagens labirínticas:

Não te aproximes demasiado das águas, podem ter braços que te puxem para que morras afogada. Não subas demasiado alto, podem vir pés ao vento que te queiram fazer cair. Não cobices demasiado o sol de verão, pode haver fogo na luz que te queime os olhos. Não te enganes com toda a neve, podem ser ursos deitados à espera de comer. Tudo na Islândia pensa. Sem pensar, nada tem provimento aqui. Milagres e mais milagres, falava assim. E tudo pensa o pior. (MÃE, 2014, p. 30).

Daí a comunhão com a natureza, pois as entidades do mundo físico são revestidas de sacralidade e personalidade; daí, também, ser essa natureza-paisagem-personagem que ajuda a compor Halla como um eu "possuído por uma alma alheia" (cf. BAKHTIN, 2006, p. 31), uma vez que várias são as vozes que incorpora: a de Sigridur, a da Islândia, a da mãe mutiladora, a do pai sonhador e a dos remotos moradores. Por isso, a sua palavra é, também, alheia, habitada por "ecos de outros enunciados (BAKHTIN, 2006, p. 294) e, plena da palavra dos outros - da natureza, da poética e da perda em sobreposição simultânea, traz consigo as ressonâncias lendárias e míticas. É, portanto, com a natureza-personagem que Halla contracena inventando a passagem, também labiríntica, dos eventos reais para a sua releitura imaginária sobre a morte, o universo feminino (imaginar o corpo como uma casa arrumada), o universo masculino (geriam as vidas com sentido prático) e a sexualidade. Sobre esta última, o despertar da sexualidade acontece com Einar - "Ele olhava para mim como se eu fosse uma ovelha tosquiada, assada, recolhida na bandeja dos seus braços, pronta a servir." (MÃE, 2014, p. 47). A iniciação sexual - "brincar de ser adulta" (MÃE, 2014, p. 49) - vem envolta em nojo, desejo, prazer, medo e, principalmente, em profanação uma vez que contrariava o conselho dado por Sigridur - "Nunca namores com ele, Halla. Tu nunca namores com o Einar" (MÃE, 2014, p. 39). No entanto, é com Einar, o ogro tolo, feio e desdentado com quem "estava proibida de fazer futuro", que começa a realizar o seu desejo de ser longe: "o Einar, por agora, é o mais longe que existe. Como se me levasse a ser outra." (MÃE, 2014, p. 51). Grávida de Einar perde ainda mais a identidade - "Era uma aberração" (MÃE, 2014, p. 64) - a mãe a amaldiçoa - "estás desgraçada, rapariga, (MÃE, 2014, p. 56) - e promete-lhe tirar a gravidez com uma borracha de desentupir canos ou com água fervente; o pai diz que ela era uma mangueira branca grávida de uma gota de água; mas é também com a gravidez que começa a ganhar a sua transformação, pois sente que "precisava de futuro, porque nascia alguém

2 Grifos nossos para destacar as entidades. 
lentamente, "um poema a começar". "O filho ocuparia o vazio deixado pela Sigridur." (MÃE, 2014, p. 69). No entanto, a gravidez não vinga, sem o filho sente-se "Uma casa assaltada. Não era alguém. Era uma casa assaltada. Um lugar que, subitamente, se desocupara. Um lugar que alguém rejeitara." (MÃE, 2014, p. 81). O filho não é enterrado: "Para a boca de deus atirei o meu filho. Num pano branco o fiz voar, como andorinha apagando na escuridão adentro. [...] Entrou para o lado absolutamente silente do poema [...] e assim o encaminhei para fora do mundo. Sem retorno." (MÃE, 2014, p. 82). Se Halla o encaminha para fora do mundo, encaminha a si para fora da infância: "Já não sou mais criança, pensei. [...] Já não sou criança, pensei com maior convicção. Não inventava mais monstros. Bastavam-me os que a realidade tinha." (MÃE, 2014, p. 130). Vários foram os acontecimentos que contribuíram para a transformação de Halla: a morte da irmã, a rejeição e a mutilação da mãe, o envolvimento com Einar e a perda do filho. Este último duplamente significativo porque interfere no desenrolar da trama e na constituição do sujeito:

Disse-lhe que não aceitava mais ser criança. As crianças não sepultam filhos. Quem sepulta um filho não tem idade. Está para lá das idades, para lá dos tempos, tem uma posse do mundo que independe de todas a limitações. A intensidade de quem sepulta um filho é semelhante a das forças inaugurais ou terminais. Pode fazer e desfazer tudo. Legitimamente lhe é conferido o poder moral de começar ou de acabar tudo. [...]. Estava mais capaz de matar que de morrer. (MÃE, 2014, p. 83).

Diante das perdas, acontece a passagem para o amadurecimento: “A vida, agora, era a direção que eu lhe conferisse. Estava com doze anos, faltava pouco para fazer treze, não me via como uma criança. Era uma mulher tão completa quanto apenas a tristeza as sabia fazer.” (MÃE, 2014, p. 89). $\mathrm{O}$ que a leva a refletir sobre a vida: "Não acontecia nada à revelia da morte, a silente figura do mundo, participante muda, cretina, criminosa jogadora. Competia-me, compreendia muito bem, a vida. Ainda que a vida fosse uma manifestação muito ténue, quase de má vontade." (MÃE, 2014, p. 94). A reflexão sobre a vida na presença da morte leva à desilusão:

Das duas, a Sigridur era a sonhadora. Se a morte não a ativesse traído, esperá-la-ia uma vida de maravilhas por diante. Mas a vida não pertencia aos sonhadores, ainda que talhados para o sucesso. A vida era dos que sobravam. Em sobrar estava a oportunidade de prosseguir e de alguma vez ser feliz. Eu sobrava. (MÃE, 2014, p. 102)

Halla é o que sobra e como rasto ou espectro de vida dimensiona a imprecisão de sua subjetividade e se situa na comparação com Sigridur:

Eu sobrava. Não tinha o caráter da minha irmã. Percebia isso cada vez melhor. Seguira-a sempre. Ela, cheia de ideias e inspirações. Eu, oca, uma existência pela rama, a ganhar conteúdo pelo fascínio que ela exercia sobre mim. Não era nada a metade valiosa da nossa vida. Eu era a metade fraca. Teria sido apenas justo que eu morresse em troca dela. Toda a maravilha que se queria das crianças estaria contida na Sigridur. Que nunca amaria o Einar. Ficaria empedernida, se fosse preciso, a fabricar um príncipe encantado que a quisesse e que dignificasse a povoação. Ela seria capaz de tudo. O seu sonho concebia tudo e todas as espertezas. O meu era apenas um modo rudimentar de a imitar. Pensei em muitas ocasiões que não éramos gémeas. Pensei que ela era genuína e eu apenas uma imitação. (MÃE, 2014, p. 102,103).

Ainda que sob o desencanto de descobrir-se como a metade fraca e uma imitação, Halla direciona seu destino: "arrancarei o coração do peito para o secar como um trapo e usar limpando apenas as coisas mais estúpidas" (MÃE, 2014, p. 145). E, por ser uma sobra, diz: "Começarei morrendo pelo coração. Gostarei sempre dele, como se gosta do que está extinto, sejam os dragões, os anjos ou as distâncias. Histórias de coisas que não voltam.” (MÃE, 2014, p. 145). Halla contou a história 
das coisas que não voltam para preencher os vazios da sua história (a menos morta que esperava o regresso absurdo da Sigridur) e para ajudar Einar a rememorar a sua história trazendo, agora, as coisas de volta e desenredando os fios da teia que o aprisionara. Halla, metaforicamente, desfez os nós da trama e como um sujeito dilacerado, inscrito entre apagamentos, esquecimentos e rupturas, assume a ambivalência das forças inaugurais e terminais. Como força terminal, toma para si o poder de acabar tudo:

Havia feito um cálculo de cada acontecimento. O lume andaria pelo chão até à mesa, subiria a mesa e já estaria pelas paredes. [...]. Os novelos de lã a esfumarem-se rápidos, apenas um artifício do fogo, uma brincadeira. [...]. Eu confirmara a maneira como trancara tudo. [...]. Eu pensei: Sigridur, corta-os com facas, mana. Corta-os desse lado, por mim. Eu sabia que ela me ouviria. Eu era gémea da morte. Deixei cair a pequena moeda com que costumava dormir. Sujei com ela o chão. Fugi. (MÃE, 2014, p. 151).

Como força inaugural, toma para si o poder da linguagem: "Olhei o mundo como palavras" (MÃE, 2014, p. 151).

\section{A performatização da poética da desumanização na errância da escrita}

No romance, o ato de ler não muda, mas a atitude daquele que lê o torna diferente. (BLANCHOT, 2011b, p. 84).

A leitura do romance vai além do enredo para compreender a duplicidade da palavra do contar tecida entre a escrita ficcional e a escrita poética:

A poesia é a linguagem segundo a qual deus escreveu o mundo. Disse o meu pai. Nós não somos mais do que a carne do poema. Terrível ou belo, o poema pensa em nós como palavras ensanguentadas. Somos palavras muito específicas, com a terna capacidade da tragédia. A tragédia, para o poema, é apenas uma possibilidade. Como um humor momentâneo. Eu perguntei: posso chamar a vida de poema. E ele respondeu: tu podes chamar a vida de poema. (MÃE, 2014, p. 45)

Se existe poesia, diz Blanchot (2011b), é porque a linguagem é um instrumento de compreensão, pois as palavras precisam ser visíveis, necessitam de uma realidade própria que se possa interpor entre o que é e o que elas expressam. Essa realidade própria que a linguagem constrói distancia-se da linguagem que representa a realidade do mundo natural uma vez que a linguagem "destrói o mundo para fazê-lo renascer no estado de sentido, de valores, significados [...]. Isto é possível na medida em que, tomando um valor sensível, ela própria se torna uma coisa, um corpo, uma potência encarnada." (BLANCHOT, 2011b, p. 45). Completa dizendo que a presença real e a afirmação material da linguagem dão o poder de suspender e despedir o mundo, isto porque a linguagem "eleva todos os elementos materiais que a compõem a uma existência superior, análoga à consciência da qual, além de ser produto, é emblema, capaz, como ela, de misterioso silêncio, fundo escuro sobre o qual tudo se declara." (BLANCHOT, 2011b, p. 46).

"Fundo escuro sobre o qual tudo se declara", a citação pode ser empregada para caracterizar o olhar de Halla, ver o 'lado de dentro', 'apenas nas costas dos olhos' para estabelecer a indissociação entre "o vivido e o poetado" (AGAMBEN, 2014, p. 103). Nas palavras do autor, a vida é aquilo que se gera na palavra e nela permanece inseparável e íntima uma vez que a linguagem se apresenta como um cruzamento inextrincável de amor, palavra e conhecimento. Na história de Halla, vida e morte são geradas na palavra que poetiza o que resta do vivido (e também o que estava por viver); vida e morte 
não sinalizam um contraponto uma vez que o que é vida estava (ou está) na morte e o que é morte está na vida, ambas entretecidas na linguagem. Por isso, Halla precisou do 'espelho' porque este permitiu suspender e despedir o mundo da realidade para deixar vir à tona o mundo imaginário ainda que sob a perspectiva da imagem opressora da morte. Conforme Foucault (2009, p. 48), a "linguagem sobre a linha da morte, se reflete: ela encontra nela um espelho; e para deter essa morte que vai detê-la não há senão um poder: o de fazer nascer em si mesma sua própria imagem em um jogo de espelhos que não tem limites.".

Essa linguagem demanda jogar esse jogo para poder perceber na escrita do romance a sua realidade verbal, o que significa considerar as palavras em seu aspecto comunicativo e sensível: "Por vezes, e sem que haja ruptura de tom, por uma concentração maior dos elementos rítmicos, a prosa se torna poesia, como se, nesses instantes privilegiados, a virtude da obra se cristalizasse para se tornar visível a nós." (BLANCHOT, 2005, p. 179). O que torna a obra visível é o procedimento performático da escrita, uma escrita que potencialmente dramatiza um acontecimento: "o que é escrito pertence à literatura, aquele que o lê está lendo literatura [...] uma retórica de espécie muito particular, destinada a fazer-nos entender que entramos no espaço fechado, separado e sagrado que é o espaço literário." (BLANCHOT, 2005, p. 302). Espaço que autoriza situar o processo criativo da ficção como cena e o acontecimento como ato criador revelado na situação narrativa. A ficção como "discurso encenado" (IZER, 1983, p. 397) traz as marcas da linguagem poética e, "pelo fato de haver poesia, há não apenas algo de transformado no universo, mas uma espécie de mudança essencial do universo [...]." "A poesia sempre inaugura outra coisa" (BLANCHOT, 2005, p. 351, grifos do autor), e, em A desumanização, a poesia inaugura o ato escritural da performance. Zumthor (2005, p. 87) denomina performance como "o ato pelo qual um discurso poético é comunicado por meio da voz e, portanto, percebido pelo ouvido". No romance, a mediação é feita pela escrita, a percepção é realizada pelo olho que acompanha pela configuração das orações, distribuição dos parágrafos e apresentação gráfica o desenho da encenação construída linguisticamente; a voz ressoa, mas muda, em silêncio e plena de significação, para reforçar as nuances da atuação/sensação da personagem. A voz poética é uma sonoridade escrita assim como a gestualidade e demais elementos característicos da encenação que são construídos entre o cênico e o poético. O 'performer literário' tem muito do performer cênico, uma vez que

o performer - ser da deriva e da errância, habitante de Kairós - o agente da passagem, inseminador e vivificador do estrato cultural: em cena aberta à comunidade, sua voz se faz gesto, seus adereços se fazem ícones, sua gesta repetitiva se faz texto. [...]. Funcionando como bricolleur na sua errância e movência o performer é o agente da inscrição, testemunho e porta-voz do mundo oralizado e memorial, que se atualiza e se torna texto nas suas andanças e vocalizações. (COHEN, 1999, 226-227).

O cênico-poético-performático é o dispositivo desencadeador de experiências sensoriais na relação estabelecida com o leitor/espectador. O corpo em cena é travestido em corporeidades, isto porque o que é encenado é a palavra, ${ }^{3}$ a potência encarnada da voz e do corpo espectrais; por isso, a cena literária comporta apenas corporeidades performatizadas na escrita poética:

Ouvi-o dizer que a minha vida era uma extensão de cor. Como árvores. Milhares de árvores que pusessem o pé nos fiordes. Tinha uma visão. Repovoar a Islândia com árvores. Eu havialhe dito muitas vezes que adoraria ajudar. Ajudaria árvore a árvore. Até ser tudo verde. Ele respondeu que nos seus poemas tudo era verde. Depois, pensou melhor e acrescentou: ou vermelho. Os poemas tinham copas. Havia um vento suave. Soprava pelos poemas e alguns

3 O poeta cria a imagem, a forma espacial da personagem e de seu mundo com material verbal: por via estética assimila e justifica de dentro o vazio de sentido e de fora a riqueza factual cognitiva dessa imagem dando-lhe significação artística. (BAKHTIN, 2006, p. 87.) 
versos eram soltos como a caminho de outras ilhas. Talvez capazes de fazerem sentido sozinhos. (MÃE, 2014, p. 73-74).

No modo de tramar o enredo, observamos o deslizamento da escrita entre a escrita ficcional e a escrita poética, prosa e poesia, isto porque a palavra poética é "livre para ser deformação" uma vez que a "literatura é um convite à transgressão" (cf. BLANCHOT, 2011b, p.58). No romance, esse 'convite' é endereçado ao leitor para compartilhar das reflexões tecidas, principalmente, sobre o oficio de narrar, a linguagem da literatura, a função do livro. Metaliteratura e experimento de linguagem sempre em estreita relação com o vivido e o poetado:

Os poemas dizia o meu pai, podem ser completos como muito do tempo e do espaço. Podem ser verdadeiramente lugares dentro dos quais passamos a viver. E havia quem cobiçasse a memória do senhor apagado. (MÃE, 2014, p. 138).

Pensava que os livros eram animais de barriga imensa para onde caíam os leitores, puxados por textos inquinados, maquiavélicos, feitos de malícias, maldades, mentiras, deturpações, transformações do quer certo em condutas erradas. Os livros tinham presas e dentes afiados e comiam gulosamente as pessoas. (MÃE, 2014, p. 108).

Os escritores teriam sempre longas contas para acertar com deus, por se atreverem a deixar as ideias mais perigosas ao serviço dos mal preparados, dos ingénuos, dos sonhadores, dos que errariam em qualquer decisão perante as questões mais elementares. Deus haveria de sentenciar cada texto e cada memória, e todos os escritores seriam triturados entre os seus dedos para caírem como pó no esquecimento do inferno. A nós competia nada, apenas assear, organizar, obedecer. Não ler, pensei, era como fechar os olhos, fechar os ouvidos, perder sentidos. As pessoas que não liam não tinham sentidos. Andavam como sem ver, sem ouvir, sem falar. Não sabiam sequer o sabor das batatas. Só os livros explicavam tudo. As pessoas que não leem apagam-se do mapa de deus. Eu disse. (MÃE, 2014, p. 109).

Tricotávamos a lã que sobrava e voltávamos aos livros, a ler tudo outra vez e só reparávamos nas palavras. Queríamos nada saber das histórias. Prestávamos atenção às palavras para sabermos como eram ditas as coisas. Porque alguns livros pareciam perfumar a linguagem, outros sujavam-na e outros ignoravam-na. Os livros podiam ser atentos ou desatentos ao modo como contavam. Nós, inspecionando muito rigorosamente, achávamos melhores aqueles que falavam como se inventassem modos de falar. Para percebermos melhor o que afinal, era reconhecido mas nunca fora dito antes, Os melhores livros inauguravam expressões. Diziam-nas pela primeira vez como se as nascessem. Ideias que nasciam para caberem nos lugares obscuros da nossa existência. Andávamos como pessoas com luzes acesas dentro. As palavras como lâmpadas na boca. Iluminando tudo no interior da cabeça. Como o cristal natural do Einar, que o deixava mágico. As palavras deixavam-nos mágicos. Eram livros que traziam feitiço e punham tudo a ser outra coisa. (MÃE, 2014, p. 125).

Nessas reflexões temos uma mostra de como as fronteiras e os limites entre os gêneros são ampliados, isto porque na ficção o que importa é "mostrar o quanto é invisível a invisibilidade" (FOUCAULT, 2009, p. 225), por isso a linguagem da ficção "não deve mais ser o poder que infatigavelmente produz e faz brilhar as imagens, mas a potência que, pelo contrário, as deslinda, as alivia de todas as suas sobrecargas, vive nelas com uma transparência interior que pouco a pouco as ilumina até fazê-las explodir e as dispersa na leveza do inimaginável (FOUCAULT, 2009, p. 225). Por isso que "escrever é um caso de devir, sempre inacabado, sempre em via de fazer-se, e que extravasa qualquer matéria vivível ou vivida." (DELEUZE, 1997, p. 11) Tal definição nos autoriza a considerar a escrita do romance como "um processo, ou mesmo uma passagem de vida que atravessa o vivível e o vivido. A escrita é inseparável do devir" (DELEUZE, 1997, p. 11). 
A escrita da ficção incorpora as qualidades da escrita poética em simultaneidade às considerações metaliterárias desdobrando-se na situação de performance: o ato de fala de Halla "torna-se ato e fabulação" (DELEUZE, 2005, p. 288); a voz na letra, potência do devir promoveu os deslizes entre os gêneros textuais, provocou a ficção que quis ser ensaio: "Ensaio é imaginação", afirma Ozick (2018, p. 225), porque "é o movimento de uma mente livre quando brinca. Embora escrito em prosa, está mais próximo da poesia do que de qualquer outro gênero. Como um poema, um verdadeiro ensaio se faz com linguagem, personagem, atmosfera, temperamento, garra e acasos."

\section{Considerações finais}

[...] mesmo se todos os homens do mundo fossem razoáveis, ainda haveria, sempre, a possibilidade de atravessar o mundo de nossos signos, o mundo de nossas palavras, de nossa linguagem, de embaralhar seus sentidos mais familiares e colocar, por meio apenas do miraculoso jorrar de algumas palavras que se entrechocam, o mundo de través. (FOUCAULT, 2016, p. 54)

O 'mundo de través' - desumano, desencantado, impotente, indiferente - situação liminar de quase-vida e quase-morte que contamina a linguagem, daí a escrita em quase-versos: "Levantada eu sobre a brancura como animal selvagem, avulso, vagando como sem propósito." E continua: “O gelo também fazia os seus espectros. Agigantavam-se figuras que se insinuavam, mais perto ou mais longe, instáveis. Acalmei. Olhei o mundo como palavras. Podia estar apenas passando pelas mais brancas, as mais vazias e longas. Haveriam de acabar.” (MÃE, 2014, p. 151). Este é o instante de deslizamento do olhar encantatório para o olhar construído no gesto transgressor para afugentar os fantasmas. Gesto que qualifica o sujeito narrador como aquele que se instaura na escrita que "coloca o indivíduo não apenas numa singularidade, mas também numa solidão que é irremediável” (FOUCAULT, 2016, p. 157).

AHalla é facultado o deslizamento de 'olhares' referido acima, na escrita do romance o deslizamento ocorre na linguagem que desde o início transitou entre a prosa e a poesia, a ficção e o ensaio poético; daí o procedimento de 'embaralhar' o discurso permeado de experiências liminares: da morte e da palavra poética performatizados na poética da desumanização. Tal procedimento que fraturou a escrita teve lugar no espaço literário, campo de experimentação da linguagem que permitiu conceber o literário como o intervalo móvel "que se designa a partir do interdito, mas abrindo-o para nele pôr a descoberto não a lei, mas o entredizer ou o vazio da descontinuidade" (BLANCHOT, 2007, p. 268, grifos do autor).

Nesse sentido reafirmamos as errâncias em espelhamento - do sujeito e da escrita literária - uma vez que ambos, metaforicamente, estão em uma situação intervalar, isto porque "nossas relações no mundo e com o mundo são sempre, finalmente, relações de potência, onde a potência está em germe na possibilidade. Ficando nos traços mais aparentes de nossa linguagem, quando falo, tenho sempre uma relação de potência." (BLANCHOT, 2001, p. 152). Halla reinventou uma saída para a desumanização na palavra poética, uma vez que "é poeticamente que o homem permanece" (BLANCHOT, 2005, p. 350) ainda que lhe tenha faltado "sonhar o que era dos sonhos" (MÃE, 2014, p. 108). Quanto à escrita, "a literatura é o risco sempre corrido e sempre assumido por cada palavra de uma frase de literatura", porque "a obra literária é feita simplesmente com a linguagem." (FOUCAULT, 2016, p. 109 e p.116), daí a potência sempre em devir da escrita literária. 


\section{Referências}

AGAMBEN, Giorgio. Categorias italianas: estudos de poética e literatura. Florianópolis: Editora da UFSC, 2014.

AGAMBEN, Giorgio. O sacramento da linguagem. Arqueologia do juramento. Belo Horizonte: Editora UFMG, 2011.

BAKHTIN, Mikhail. Estética da criação verbal. São Paulo: Martins Fontes, 2006.

BLANCHOT, Maurice. A conversa infinita 1: a experiência limite. São Paulo: Escuta, 2001.

BLANCHOT, Maurice. A conversa infinita 2: a experiência limite. São Paulo: Escuta, 2007.

BLANCHOT, Maurice. A parte do fogo. Rio de Janeiro: Rocco, 2011b.

BLANCHOT, Maurice. O espaço literário. Rio de Janeiro: Rocco, 2011a.

BLANCHOT, Maurice. O livro por vir. São Paulo: Martins Fontes, 2005.

COHEN, Renato. Performance como linguagem. São Paulo: Perspectiva, 2002.

COHEN, Renato. Performance e contemporaneidade: da oralidade à cibercultura. In: FERREIRA, Jerusa Pires. Oralidade em tempo \&espaço: colóquio Paul Zumthor. São Paulo: EDUC, 1999. p. 225-239.

DELEUZE, Gilles. A imagem-tempo. São Paulo: Brasiliense, 2005.

DELEUZE, Gilles. Crítica e clínica. São Paulo: Ed. 34, 1997.

DURAND, Gilbert. As estruturas antropológicas do imaginário: introdução à arquetipologia geral. 3. ed. São Paulo: Martins Fontes, 2002.

ELIADE, Mircea. Mito e realidade. São Paulo: Perspectiva, 1991.

ELIADE, Mircea. O sagrado e o profano. São Paulo: Martins Fontes, 1995.

FOUCAULT, Michel. A grande estrangeira: sobre literatura. Belo Horizonte: Autêntica, 2016.

FOUCAULT, Michel. Estética: literatura e pintura, música e cinema. 2. ed. Rio de Janeiro: Forense Universitária, 2009.

ISER, W. Os atos de fingir ou o que é fictício no texto ficcional. In: LIMA, Luiz Costa. Teoria da literatura em suas fontes. 2. ed. Rio de Janeiro: Francisco Alves, 1983. p. 384; 416.

MÃE, Valter Hugo. A desumanização. São Paulo: Cosac Naify, 2014.

MORIN, Edgar. O cinema e o homem imaginário. Lisboa: Moraes Editora, 1980.

OZICK, Cynthia. Retrato do ensaio como corpo de mulher. In: PIRES, Paulo Roberto (Org.). Doze ensaios sobre o ensaio: Antologia Serrote. São Paulo: IMS, 2018. p. 225-233.

ZUMTHOR, Paul. Escritura e nomadismo: entrevistas e ensaios. Tradução de Jerusa Pires Ferreira, Sonia Queiroz. Cotia. São Paulo: Ateliê Editorial, 2005. 
